[RAdIOCARBON, Vol 25, No 3, 1983, P 810-830]

\title{
CARBON ISOTOPE ANALYSIS OF LAND SNAIL SHELLS: IMPLICATIONS FOR CARBON SOURCES AND RADIOCARBON DATING
}

\author{
GLENN A GOODFRIEND \\ Department of Zoology, University of Florida, Gainesville, Florida 32611 \\ and \\ DARDEN G HOOD \\ Radiocarbon Dating Laboratory, University of Miami, \\ Miami, Florida 33124
}

\begin{abstract}
C}$ and ${ }^{14} \mathrm{C}$ analyses were performed on a series of modern Jamaican land snails in order to quantitatively determine the sources of shell carbon. A model of these carbon sources, the pathways by which carbon reaches the shell, and the fractionation processes involved are presented. The contribution of limestone to shell carbonate is variable but may comprise up to $33 \%$ of the shell. About $25-40 \%$ of shell carbonate is derived from plants and about $30-60 \%$ from atmospheric $\mathrm{CO}_{2}$. Variation among populations and species with respect to ${ }^{13} \mathrm{C}$ and ${ }^{14} \mathrm{C}$ is attributed to the effects of limestone incorporation, snail size (as it affects $\mathrm{CO}_{2}$ exchange rate), physiological characteristics (presence of urease, respiration rate), and activity patterns of the snails. A formula for correction for isotopic fractionation of ${ }^{14} \mathrm{C}$ of shell carbonate, based on ${ }^{13} \mathrm{C}$ measurements, is derived. Bicarbonate-aragonite fractionation is apparently very minimal. Shell organic carbon appears to be derived largely from plants but also to a lesser extent from inorganic hemolymph carbon. This introduces the possibility of a small age anomaly of shell organic ${ }^{14} \mathrm{C}$ due to limestone incorporation.
\end{abstract}

\section{INTRODUCTION}

An understanding of the factors controlling the isotopic composition of the carbon of land snail shells is of considerable importance to a variety of problems. Radiocarbon dating of land snail shells depends on estimating the original ${ }^{14} \mathrm{C}$. This is determined by the relative contributions of carbon sources differing in isotopic composition, plus the effects of fractionation. Of particular importance is the incorporation of limestone into the shells, leading to an anomalous ${ }^{14} \mathrm{C}$ content (Goodfriend and Stipp, in press). Land snail shell ${ }^{13} \mathrm{C}$ has recently been investigated as a possible paleoecological indicator (Yapp, 1979; Magaritz, Heller, and Volokita, 1981; Magaritz and Heller, in press). Magaritz and Heller (in press) suggest that shell $\delta^{13} \mathrm{C}$ may indicate microhabitat conditions or characteristics of vegetation. The isotopic composition of land snail shells may also provide information regarding the physiology of shell deposition.

Researchers do not agree on the source(s) of land snail shell carbonate. De Jorge and Haeser (1968) and Tamers (1970) suggested that $\mathrm{CO}_{2}$ released from respiration of food is a source of shell carbonate carbon. Rubin, Likins, and Berry (1963) and Goodfriend and Stipp (in press) showed that ingested limestone is a shell carbonate source in some land snails. Campbell and Speeg (1969) demonstrated that the carbon in ${ }^{14} \mathrm{C}$ labeled urea was incorporated into the shell carbonate of a land snail species. Still others (eg, De Niro and Epstein, 1978; Magaritz and Heller, in press) consider the source of shell carbonate carbon to be unknown. In this study we have used data on the age, ${ }^{14} \mathrm{C}$ content, and ${ }^{13} \mathrm{C}$ content of 
land snail shells to estimate the relative importance of the possible sources of shell carbonate.

Fractionation of carbon isotopes in various reactions leading to eventual deposition in shell would also affect the isotopic composition of the shell. In laboratory experiments of carbonate precipitation from inorganic solutions under equilibrium conditions, ${ }^{13} \mathrm{C}$ in aragonite, the calcium carbonate mineral of which land snails are composed (B $\phi$ ggild, 1930), was fractionated by ca $2.7 \%$ relative to bicarbonate (Rubinson and Clayton, 1969). Empirical results indicate that in aquatic mollusks there is only a rather slight fractionation of shell carbonate carbon relative to the bicarbonate of the medium (Mook and Vogel, 1968; Fritz and Poplawski, 1974). Dissolution of gaseous $\mathrm{CO}_{2}$ in water favors heavier isotopes, thus leading to a fractionation of ${ }^{13} \mathrm{C}$ of $\mathrm{ca}+8 \%$ of dissolved bicarbonate relative to gaseous $\mathrm{CO}_{2}$ (Mook, Bommerson, and Staverman, 1974). If in some land snail shell carbon is derived from aerial $\mathrm{CO}_{2}$, a more significant fractionation (relative to the medium) is to be expected than in aquatic mollusks.

Below we consider the possible sources of shell carbonate carbon and the possible pathways by which carbon reaches the shell. We then present ${ }^{13} \mathrm{C}$ and ${ }^{14} \mathrm{C}$ analyses of a series of modern pre- and post-bomb land snails from Jamaica ( 8 populations from limestone areas and 1 from a nonlimestone area). From these data we estimate the contributions of the ultimate carbon sources to shell carbonate. These findings are discussed in relation to problems of ${ }^{14} \mathrm{C}$ dating of land snail shells - the possible use of ${ }^{13} \mathrm{C}$ data to estimate limestone anomaly and to correct for fractionation effects. We examine the factors controlling the carbon isotope content of shells and assess the potential for the use of ${ }^{13} \mathrm{C}$ as a paleoenvironmental indicator and for elucidating the mechanism of shell carbonate deposition. Finally, we analyze the shell organic fraction for ${ }^{13} \mathrm{C}$ and discuss its sources and suitability for ${ }^{14} \mathrm{C}$ dating. A list of the material analyzed is given in the appendix.

A MODEL OF CARBON FLOW INTO SHELL GARBONATE

There are three possible ultimate sources of carbon - plant carbon, atmospheric $\mathrm{CO}_{2}$, and limestone - each differing in isotopic composition. These may end up as shell carbonate by a variety of pathways (fig 1 ).

Shell carbonate is deposited from bicarbonate in the extrapallial fluid (Wilbur, 1972). Laboratory studies of inorganic systems have shown aragonite carbon to be slightly positively fractionated with respect to the bicarbonate carbon from which it is precipitated (Rubinson and Clayton, 1969). Shell carbonate may also be dissolved internally under certain circumstances (Chan and Saleuddin, 1974; Poulicek and Jaspar-Versali, 1982). Bicarbonate in the extrapallial fluid is derived primarily from the bicarbonate of the hemolymph. But some might also be derived by direct diffusion of $\mathrm{CO}_{2}$ from the environment at the mantle edge. A mechanism of $\mathrm{CO}_{2}$ production (and not incidentally $\mathrm{NH}_{3}+$ production, which raises the $\mathrm{pH}$ and thus favors carbonate deposition) in the mantle by breakdown of urea by urease has been demonstrated in land snails (Speeg and Camp- 


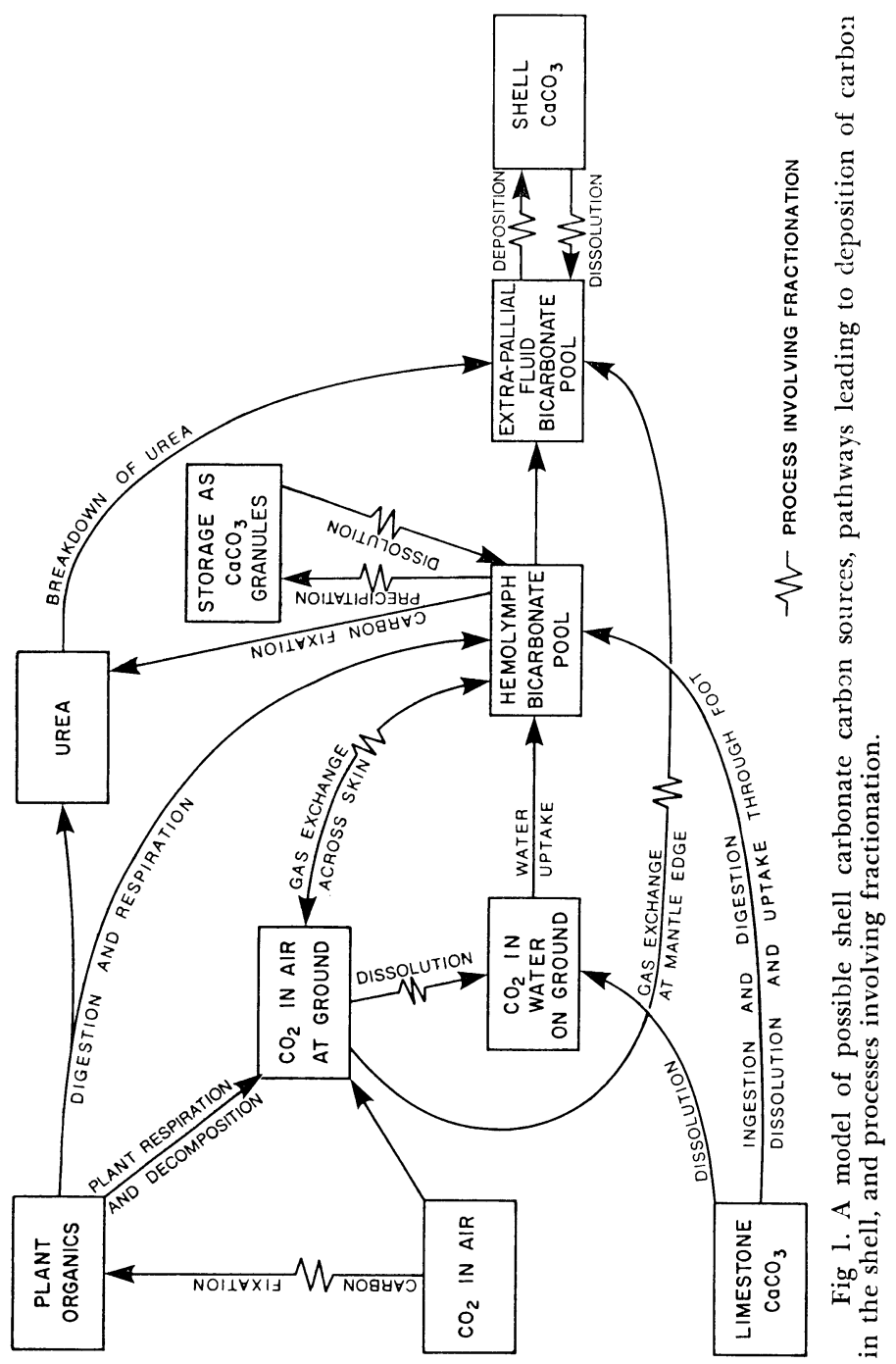


bell, 1968; Campbell and Speeg, 1969). The carbon of urea is derived from arginine, which is synthesized de novo in the ornithine cycle (Horne, 1973); the carbon fixation step occurs in the mitochondria. This carbon comes primarily from $\mathrm{CO}_{2}$ released from the respiration of plant material in the citric acid (Krebs) cycle (Horne, 1977) and to a lesser extent from hemolymph bicarbonate (Tramell and Campbell, 1972), which diffuses into the mitochondria. Thus, the $\mathrm{CO}_{2}$ released at the mantle by urea breakdown should be of predominantly plant origin. It should be noted that only some land snails possess urease. Other land snails generate $\mathrm{NH}_{3}+$ by the breakdown of adenosine, without the release of $\mathrm{CO}_{2}$ (Campbell and Boyan, 1976; Loest, 1979). In these snails, shell carbonate should be primarily of hemolymph bicarbonate origin, while for snails with urease, it should be a mixture of hemolymph bicarbonate and urea carbon.

The isotopic composition of hemolymph bicarbonate is probably due to a variety of processes. $\mathrm{CO}_{2}$ is exchanged across the skin with $\mathrm{CO}_{2}$ in the air and equilibrates with bicarbonate, with a large associated fractionation effect. Some of the aerial $\mathrm{CO}_{2}$ at the ground may be derived from decomposed plant material. Respiratory $\mathrm{CO}_{2}$ is produced in mitochondria from ingested plant carbon and would diffuse into the hemolymph. Water on the ground, containing a small amount of dissolved $\mathrm{CO}_{2}$, is taken up by land snails through the skin and perhaps also by drinking (Pusswald, 1948). This water would be rainwater, containing $\mathrm{CO}_{2}$ derived from the atmosphere (with associated fractionation), $\mathrm{CO}_{2}$ released from decomposition of leaves, and, in some areas, possibly some dissolved limestone carbonate. Major inputs of limestone-derived carbon may come from ingestion of limestone (Rubin, Likins, and Berry, 1963) and its subsequent dissolution in the gut and diffusion into the hemolymph, or from uptake through the foot of limestone dissolved by foot secretions (Frick, 1965). Carbonate may be stored as calcium carbonate granules, mostly in the foot and digestive gland. This carbonate is precipitated from the hemolymph and may be released back into it upon dissolution of the granules (Fournié and Chétail, 1982). Thus, hemolymph bicarbonate is probably a mixture of plant, atmospheric, and (in some areas) limestone carbon.

\section{ESTIMATION OF THE CONTRIBUTION OF GARBON SOURCES TO SHELL GARBONATE}

Since each of the ultimate sources of shell carbonate differs in isotopic composition, it is possible from knowledge of the age of shells and their ${ }^{13} \mathrm{C}$ and ${ }^{14} \mathrm{C}$ content to estimate the relative contribution of each of these sources. A number of assumptions must be made.

It is assumed that all carbon is ultimately derived only from air, plants (living or recently dead - the usual food source of snails), and limestone. Thus,

$$
\mathrm{P}_{\mathrm{A}}+\mathrm{P}_{\mathrm{P}}+\mathrm{P}_{\mathrm{L}}=\mathbf{1}
$$

where $P_{A}=$ the proportion of air-derived carbon, $P_{P}=$ the proportion of plant-derived carbon, and $\mathrm{P}_{\mathrm{L}}=$ the proportion of limestone-derived carbon in shell carbonate. 
The ${ }^{13} \mathrm{C}$ content of shell carbon sources is assumed to be as follows: $\delta^{13} \mathrm{C}_{\mathrm{P}}=-27 \%$ (mean value for tropical plants; Degens, 1969); $\delta^{13} \mathrm{C}_{\mathrm{L}}=0$ (Craig, 1954);

effective $\delta^{13} \mathrm{C}_{\mathrm{A}}=+1 \%$ o (We assume the actual $\delta^{13} \mathrm{C}_{\mathrm{A}}=-7 \%$ o (Degens, 1969), but that this is fractionated by $+8 \%$ o (see above) upon dissolving in water in the snail or in water subsequently taken up by the snail).

$\delta^{13} \mathrm{C}$ is defined as $1000\left[\left(\mathrm{R} / \mathrm{R}_{\mathrm{PNB}}\right)-1\right]$ where $\mathrm{R}$ is the ${ }^{13} \mathrm{C} /{ }^{12} \mathrm{C}$ ratio and $\mathrm{PDB}$ refers to the Pee Dee Belmnite, the standard against which ${ }^{13} \mathrm{C}$ is measured. The ${ }^{13} \mathrm{C}$ content of the shell $\left(\delta^{13} \mathrm{C}_{\mathrm{s}}\right)$ would be

$$
\delta^{13} \mathrm{C}_{\mathrm{S}}=\delta^{13} \mathrm{C}_{\mathrm{A}}\left(\mathrm{P}_{\mathrm{A}}\right)+\delta^{13} \mathrm{C}_{\mathrm{P}}\left(\mathrm{P}_{\mathrm{P}}\right)+\delta^{13} \mathrm{C}_{\mathrm{L}}\left(\mathrm{P}_{\mathrm{L}}\right)=\mathrm{P}_{\mathrm{A}}-27 \mathrm{P}_{\mathrm{P}} .
$$

In order to estimate the ${ }^{14} \mathrm{C}$ content of carbon sources, fractionation must be taken into account. Fractionation refers here to differential reaction rates of carbon isotopes and the differences in isotopic composition of compounds resulting from these. The correction factor for fractionation of material 1 relative to material 2 is given by

$$
A_{1}=A_{2}\left(R_{1} / R_{2}\right)^{2} \text {, }
$$

where A represents ${ }^{14} \mathrm{C}$ activity (Wigley and Muller, 1981).

Wood (with $\delta^{13} \mathrm{C}=-25 \%$, or $\mathrm{R}=\left(1+\frac{\delta^{13} \mathrm{C}}{1000}\right) \mathrm{R}_{\mathrm{PDB}}=0.975 \mathrm{R}_{\mathrm{PDB}}$ ) serves as the standard against which ${ }^{14} \mathrm{C}$ activity is measured. Tropical plants are slightly deficient in heavier carbon isotopes (mean $\delta^{13} \mathrm{C}=$ $-27 \%$ ). Their ${ }^{14} \mathrm{C}$ activity can be calculated as

$$
\mathrm{A}_{\mathrm{P}}=\mathrm{A}_{\mathrm{CW}}\left(\frac{0.973 \mathrm{R}_{\mathrm{PDB}}}{0.975 \mathrm{R}_{\mathrm{PDB}}}\right)^{2}=0.996 \mathrm{~A}_{\mathrm{CW}},
$$

where $\mathrm{A}_{\mathrm{CW}}$ is the ${ }^{14} \mathrm{C}$ activity of contemporary wood, $i e$, wood at the time of shell deposition.

The ${ }^{14} \mathrm{C}$ activity of atmospheric $\mathrm{CO}_{2}$ can be calculated, based on a $\delta^{13} \mathrm{C}$ of $-7 \%$, as:

$$
\mathrm{A}_{\mathrm{CO}_{2}}=\mathrm{A}_{\mathrm{CW}}\left(\frac{0.993 \mathrm{R}_{\mathrm{PDB}}}{0.975 \mathrm{R}_{\mathrm{PDB}}}\right)^{2}=1.037 \mathrm{~A}_{\mathrm{CW}} .
$$

Gaseous $\mathrm{CO}_{2}$ dissolving in an aqueous medium (snail hemolymph or water taken up by a snail) will be fractionated by a factor of $\alpha=\frac{R_{\text {bicarbonate }}}{\mathbf{R}_{\mathrm{CO}_{2}}}$ $\approx 1.008$ (Mook, Bommerson, and Staverman, 1974; Emrich, Ehhalt, and Vogel, 1970). So the effective ${ }^{14} \mathrm{C}$ activity of atmospherically-derived carbon would be

$$
\mathrm{A}_{\mathrm{A}}=\mathrm{A}_{\mathrm{CO}_{2}}(1.008)^{2}=1.016 \mathrm{~A}_{\mathrm{CO}_{2}} .
$$

Substituting from equation 5 , we have

$$
\mathrm{A}_{\mathrm{A}}=1.016(1.037) \mathrm{A}_{\mathrm{CW}}=1.054 \mathrm{~A}_{\mathrm{CW}} .
$$


The ${ }^{14} \mathrm{C}$ activity of limestone $\left(\mathrm{A}_{\mathrm{L}}\right)$ is taken to be 0 since all limestones from which snails were collected were $>50,000$ years old, thus effectively lacking in ${ }^{14} \mathrm{C}$.

The ${ }^{14} \mathrm{C}$ activity of shell carbonate $\left(\mathrm{A}_{\mathrm{S}}\right)$ would be the sum of the relative contributions of each of these three ultimate carbon sources:

$$
\begin{aligned}
\mathrm{A}_{\mathrm{S}} & =0.996\left(\mathrm{~A}_{\mathrm{CW}}\right)\left(\mathrm{P}_{\mathrm{P}}\right)+1.054\left(\mathrm{~A}_{\mathrm{CW}}\right)\left(\mathrm{P}_{\mathrm{A}}\right)+0 \\
& =\mathrm{A}_{\mathrm{CW}}\left(0.996 \mathrm{P}_{\mathrm{P}}+1.054 \mathrm{P}_{\mathrm{A}}\right) .
\end{aligned}
$$

Thus, from equations 1,2 , and 8 , we can calculate $P_{P}, P_{A}$, and $P_{L}$ from $\delta^{13} C_{S}, A_{S}$, and $A_{C w}$. Rearranging equation 2, we have

$$
\mathrm{P}_{\mathrm{A}}=27 \mathrm{P}_{\mathrm{P}}+\delta^{13} \mathrm{C}_{\mathrm{S}}
$$

And substituting for $\mathrm{P}_{\mathrm{A}}$ in equation 8 , we get

$$
\mathrm{A}_{\mathrm{S}}=\mathrm{A}_{\mathrm{CW}}\left[0.996 \mathrm{P}_{\mathrm{P}}+1.054\left(27 \mathrm{P}_{\mathrm{P}}+\delta^{13} \mathrm{C}_{\mathrm{S}}\right)\right] \text {. }
$$

Solving this for $\mathrm{P}_{\mathrm{P}}$, we have

$$
\mathrm{P}_{\mathrm{P}}=0.03395 \frac{\mathrm{A}_{\mathrm{S}}}{\mathrm{A}_{\mathrm{CW}}}-0.03578 \delta^{13} \mathrm{C}_{\mathrm{S}} .
$$

$\mathrm{P}_{\mathrm{L}}$ can be conveniently calculated by rearranging equation 1 :

$$
\mathbf{P}_{\mathrm{L}}=1-\left(\mathbf{P}_{\mathrm{P}}+\mathrm{P}_{\mathrm{A}}\right) \text {. }
$$

For specimens collected in 1910 and before, $A_{C w}$ was taken as $100 \%$ of modern wood ${ }^{1}\left(\mathrm{~A}_{\mathrm{MW}}\right)$ corrected for ${ }^{14} \mathrm{C}$ depletion due to age. This is calculated by

$$
\text { year of collection }-1950=8035 \ln \frac{A_{C W}}{A_{M W}}
$$

(modified from Tamers, 1970). For 1932 specimens, depletion of ${ }^{14} \mathrm{C}$ due to the industrial (Suess) effect was corrected for by taking $\mathrm{A}_{\mathrm{Cw}}=98 \%$ (Cain, 1979).

Post-1954 material was affected by the pronounced enrichment of ${ }^{14} \mathrm{C}$ due to the atomic bomb effect. Since the early 1960's, plant and atmospheric ${ }^{14} \mathrm{C}$ have been decreasing significantly (Barrette et al, 1980). Thus, to calculate $\mathrm{A}_{\mathrm{CW}}$ the exact year that the shell carbonate was deposited must be known. This was possible only for one of the post-bomb populations, Pleurodonte lucerna from Green Grotto Caves. These specimens were collected as subadults and must have deposited the majority of the shell carbonate during the year they were collected (1981). For the other post-bomb $P$ lucerna, the age of the snails at the time of collection was unknown. $P$ lucerna may live for some 10 years or more but reaches full adult size in 2 or 3 years, after which it ceases to grow (Goodfriend, unpub observations). The degree of wear of the periostracum gives a rather rough indication of the age of the specimens. As a reference for $\mathbf{A}_{\mathrm{Cw}}$ estimates, recently fallen leaf litter (the food source for Pleurodonte and

\footnotetext{
${ }^{1}$ Defined as the ${ }^{14} \mathrm{C}$ activity of 1890 wood (pre-industrial effect) corrected to AD 1950.
} 
many other land snails) was analyzed for ${ }^{14} \mathrm{C}$. Leaf litter (Ocotea staminea [Griseb] Mez) collected in 1980 gave a ${ }^{14} \mathrm{C}$ value of $127 \%$ modern, corrected for fractionation $\left(\delta^{13} \mathrm{C}=-29.29\right)$ to $126 \%$ modern $\left(=\mathrm{A}_{\mathrm{CW}}\right)$. To calculate $\mathrm{A}_{\mathrm{CW}}$ for other years, we assumed that ${ }^{14} \mathrm{C}$ has been decreasing at the rate of $3 \%$ per year, based on the data of Barrette et al (1980). It should be noted that an uncertainty of two years for the year of shell deposition of adult post-bomb Pleurodonte would produce an uncertainty of $6 \%$ modern for estimated $A_{\mathrm{CW}}$. Thus, the estimates for these specimens are only approximate.

For determination of ${ }^{14} \mathrm{C}$ of shell carbonate, shells were dissolved in $\mathrm{H}_{3} \mathrm{PO}_{4}$. The resultant $\mathrm{CO}_{2}$ was converted to benzene and counted by liquid scintillation. For ${ }^{13} \mathrm{C}$ measurements of shell carbonate, shells were dissolved in $\mathrm{H}_{3} \mathrm{PO}_{4}$ and the resultant $\mathrm{CO}_{2}$ analyzed in a mass spectrometer. The error of measurement for ${ }^{13} \mathrm{C}$ is $<0.04 \%$, and usually ca $0.01 \%$.

\section{SOURCES OF SHELL CARBONATE CARBON AND FACTORS AFFECTING}

THEIR CONTRIBUTION TO SHELL CARBONATE

Table 1 gives the carbon isotope data for the specimens analyzed, plus estimates of the proportion of shell carbonate carbon derived ultimately from plants, atmospheric $\mathrm{CO}_{2}$, and limestone. It is immediately evident that all three sources of carbonate carbon are relatively important in some or all populations. The limestone contribution is variable, indistinguishable from 0 in Pleurodonte carmelita (from a non-limestone area) and P lucerna from Heron Hill, given the uncertainties of the estimates. Limestone-derived carbon makes up nearly $1 / 3$ of the shell in other populations (P sublucerna ${ }^{2}$ from Port Antonio and Urocoptis ambigua). Plant-derived carbon makes up ca $25-40 \%$ of the shell. In most cases, carbon derived from the atmosphere is the most important shell component, contributing some $30-60 \%$ of shell carbonate carbon. Since some of the plant-derived carbon may enter the snail as $\mathrm{CO}_{2}$ from the air (derived from plant decomposition), the atmosphere may be even more important as a proximal source of carbon than estimated here.

We expected that as the contribution of limestone increases, the $\delta^{13} \mathrm{C}$ of the shell carbonate should also increase, since limestone is enriched in ${ }^{13} \mathrm{C}$ relative to observed shell carbonate values. We did find this relationship (fig 2) but it is relatively weak, with variation in the proportion of limestone-derived carbon accounting for only ca $1 / 4$ of the variation in shell $\delta^{13} \mathrm{C}$. A simple linear regression of $\delta^{13} \mathrm{C}$ on proportion of limestonederived carbon gives the y-intercept (estimated $\delta^{13} \mathrm{C}$ with no limestone input to shell) as -9.89 . If we assume that limestone has only a direct effect on $\delta^{13} \mathrm{C}$ ( $i e$, the proportion of limestone is independent of the $\delta^{13} \mathrm{C}$ of the non-limestone portion of shell carbon), then shells with, eg, 0.30 of their carbon from limestone should theoretically have a mean value of $0.70(-9.89)+0.30(0)=-6.92$. This is rather more than the value of

${ }^{2}$ Pleurodonte sublucerna and $P$ lucerna comprise a semispecies complex. They are distinct in some areas but intergrade in other areas (Goodfriend, Clinal variation and natural selection in the land snail Pleurodonte lucerna in western St Ann Parish, Jamaica, ms in preparation). 


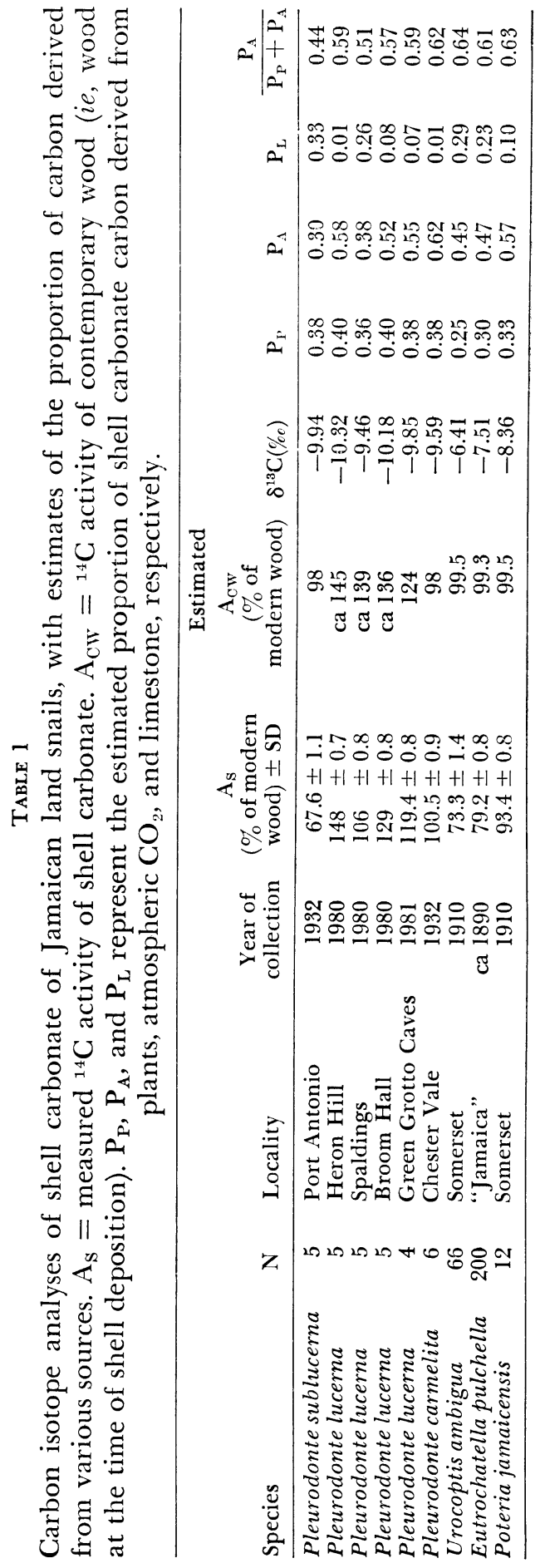


-8.28 predicted by the regression. The slope of the theoretical line $(b=$ 9.90) differs from the empirical slope with a $p \approx 0.30$ (t-test, 2-tailed). Thus this provides no convincing evidence that limestone has other than a direct effect on shell ${ }^{13} \mathrm{C}$ content. There are clearly other more important factors influencing ${ }^{13} \mathrm{C}$ levels. The result is that $\delta^{13} \mathrm{C}$ is a fairly poor predictor of $\mathrm{P}_{\mathrm{L}}$ and so is of limited use for estimation of age anomalies due to incorporation of limestone into the shell.

The various genera analyzed differ with respect to $\delta^{13} \mathrm{C}$. In order to test the generality of this pattern, ${ }^{13} \mathrm{C}$ analyses were performed on additional species and populations (table 2). The two species of the prosobranch family Helicinidae (Eutrochatella pulchella and Alcadia brownei) and the three populations ( 2 species) of the pulmonate Urocoptis (family Urocoptidae) show relatively high ${ }^{13} \mathrm{C}$ content - higher than any of the eight Pleurodonte (family Camaenidae) analyzed. Poteria (family Poteriidae) have intermediate levels of ${ }^{13} \mathrm{C}$. No consistent differences between pulmonate vs prosobranch taxa are observed.

Because these different species tend to differ in size, the ${ }^{13} \mathrm{C}$ differences found might be related to size rather than to taxonomic relationships. In order to clarify this problem, the internal volume of the shells was estimated by weighing the shell, filling it with water, and reweighing it. The internal volume of the shell was calculated as (mass after - mass before) $\times$ $1.0 \mathrm{ml} / \mathrm{g}$. Average-sized shells from the same populations as the specimens analyzed (or similarly sized shells from other populations of the same species) were used to estimate volume.

Apparent differences in ${ }^{13} \mathrm{C}$ among taxa are shown in figure 3. In the lower size range $(<4 \mathrm{ml})$, volume and $\delta^{13} \mathrm{C}$ seem to be correlated. However, no such relationship is seen among the larger Pleurodonte. The

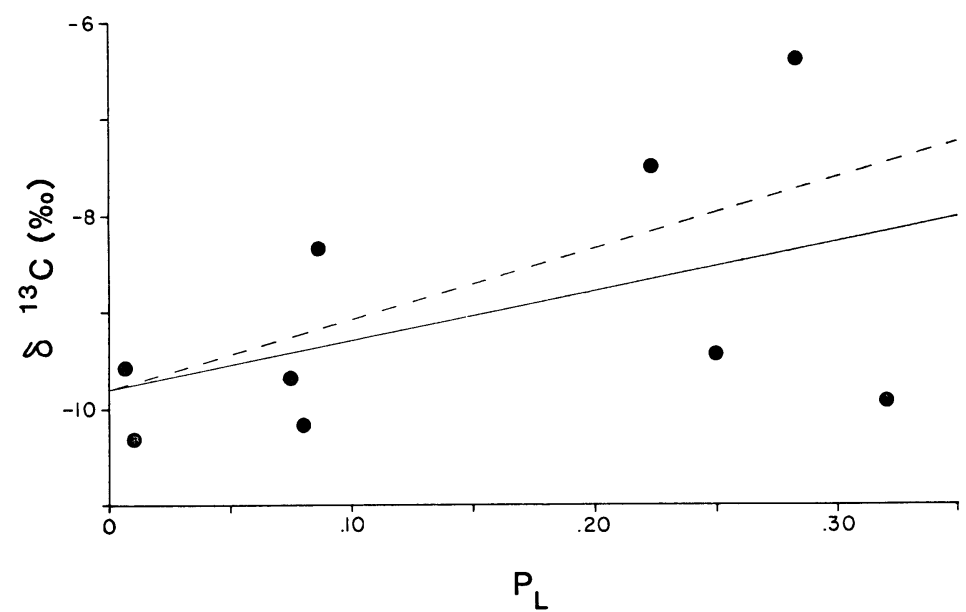

Fig 2. $\delta^{13} \mathrm{C}$ of shell carbonate in relation to the proportion of shell carbonate carbon derived from limestone $\left(\mathrm{P}_{\mathrm{L}}\right) . \mathrm{r}=0.494(\mathrm{p}>0.05)$. Regression line (solid line) is $\delta^{13} \mathrm{C}=5.36\left(\mathrm{P}_{\mathrm{L}}\right)-9.89$ and $\mathbf{R}^{2}=0.244$. Given the $\mathrm{Y}$ intercept as -9.89 , the theoretical relationship (dashed line) is $\delta^{13} \mathrm{C}=9.90\left(\mathrm{P}_{\mathrm{L}}\right)-9.89$. 
Table 2

${ }^{13} \mathrm{C}$ analyses of shell carbonate carbon. Pleurodonte lucerna were analyzed individually

\begin{tabular}{|c|c|c|c|}
\hline Species & $\mathbf{N}$ & Locality & $\delta^{13} \mathrm{C}(\% 0)$ \\
\hline Pleurodonte lucerna & 2 & Colliston & $-9.19,-9.34$ \\
\hline $\begin{array}{l}\text { Pleurodonte lucerna } \\
\quad \text { (juvenile) }\end{array}$ & 1 & Cedar Valley & -9.21 \\
\hline $\begin{array}{l}\text { Pleurodonte lucerna } \\
\text { (juvenile) }\end{array}$ & 1 & Rat Trap & -9.72 \\
\hline Pleurodonte lucerna & 3 & Cedar Valley & $-10.33,-10.82,-11.44$ \\
\hline Urocoptis ambigua & 9 & Martins Hill & -8.22 \\
\hline Urocoptis megacheila & 2 & Midgham & -9.12 \\
\hline Alcadia brownei & 4 & Higgin Land & -7.54 \\
\hline Poteria varians & 4 & Albion & -9.93 \\
\hline Poteria varians & 3 & Alexandria Pen & -10.33 \\
\hline
\end{tabular}

juvenile Plcurodonte fall within the range of values for adults, although they are in the higher part of that range. At Cedar Valley, all adults have a lower $\delta^{13} \mathrm{C}$ than the juvenile. Thus at least some variation in $\delta^{13} \mathrm{C}$ seems to be size-dependent. Whether the general trend toward high ${ }^{13} \mathrm{C}$ with smaller size is an effect of differences among taxa or of size alone cannot be determined from these data.

Since the surface area/volume ratio increases with decreasing size, exchange with atmospheric $\mathrm{CO}_{2}$ might be more important in smaller snails. This would lead to a greater dominance of aerial carbon relative to plant carbon (released from snail respiration) in smaller snails and therefore a relatively higher ${ }^{13} \mathrm{C}$ content of the shell. In order to test this relationship, the proportion of non-limestone carbon that is derived from atmospheric

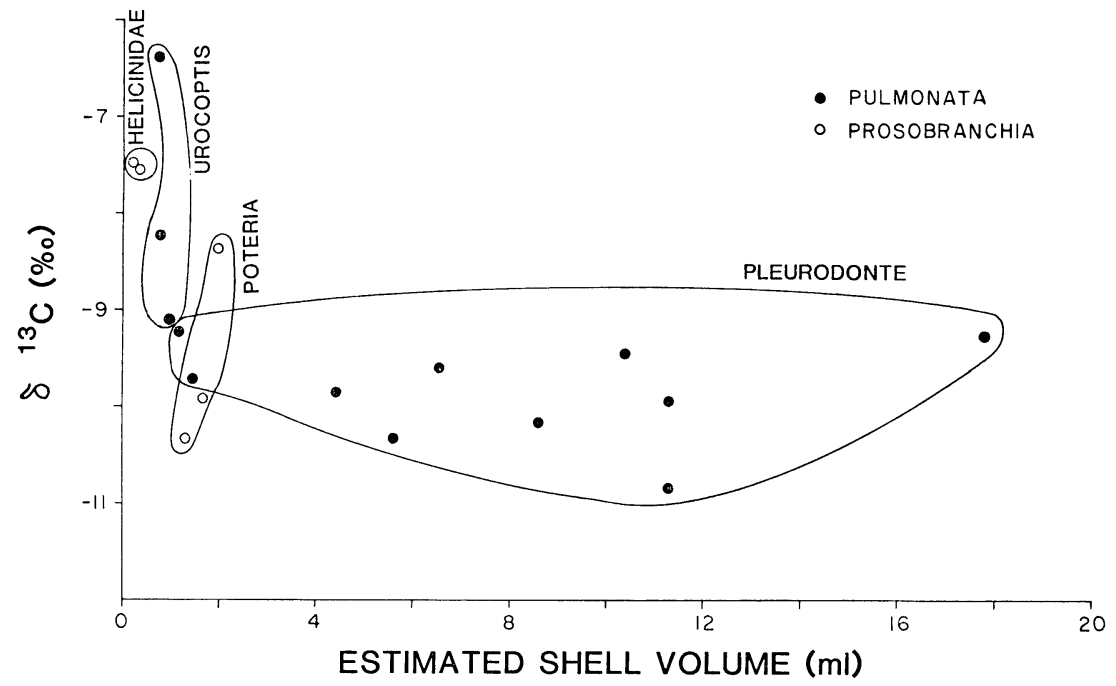

Fig 3. $\delta^{13} \mathrm{C}$ of shell carbonate vs estimated shell volume. 
sources $\left(\mathrm{P}_{\mathbf{A}} /\left[\mathrm{P}_{\mathbf{A}}+\mathrm{P}_{\mathrm{P}}\right]\right)$ was compared to snail size. The direct effect of limestone on shell ${ }^{13} \mathrm{C}$ is thereby factored out. Figure 4 shows this relationship is very strong, with shell volume accounting for almost $3 / 4$ of the variation in the aerial contribution to non-limestone shell carbonate carbon. This result is consistent with the proposed mechanism.

Note that the contribution of aerial carbon to the non-limestone portion of the shell is lower in shells with large amounts of limestonederived carbon; the converse is true for shells with small amounts of limestone-derived carbon. These data suggest an interaction between the limestone and aerial contributions to the shell — limestone seems to differentially affect the aerial and plant carbon contributions. This relationship would account for the observation (see above) that the effect of limestone on shell $\delta^{13} \mathrm{C}$ is slightly less than expected, although not significantly so. The mean $\delta^{13} \mathrm{C}$ of limestone $(0)$ is very close to the effective $\delta^{13} \mathrm{C}$ of gaseous $\mathrm{CO}_{2}(+1 \%)$. Thus the enrichment in ${ }^{13} \mathrm{C}$ expected from the contribution of limestone is partially offset by a correlated decrease in the contribution of ${ }^{13} \mathrm{C}$-rich aerial $\mathrm{CO}_{2}$. The probable explanation for the relationship between limestone and aerial contributions is that since ingested limestone would release considerable amounts of $\mathrm{CO}_{2}$ in the snail, the bicarbonate concentration of the hemolymph would be raised and diffusion of aerial $\mathrm{CO}_{2}$ into the snail would be decreased. The contribution of plant-derived carbon to the hemolymph bicarbonate would not be affected if respiration is the major input of plant carbon.

Besides the effect of differences in size and limestone intake, variation in $\delta^{13} \mathrm{C}$ among taxa might be caused by differences in their physiological and behavioral characteristics. Differences in respiration rate might produce differences in the plant contribution to shell carbonate. Taxa may

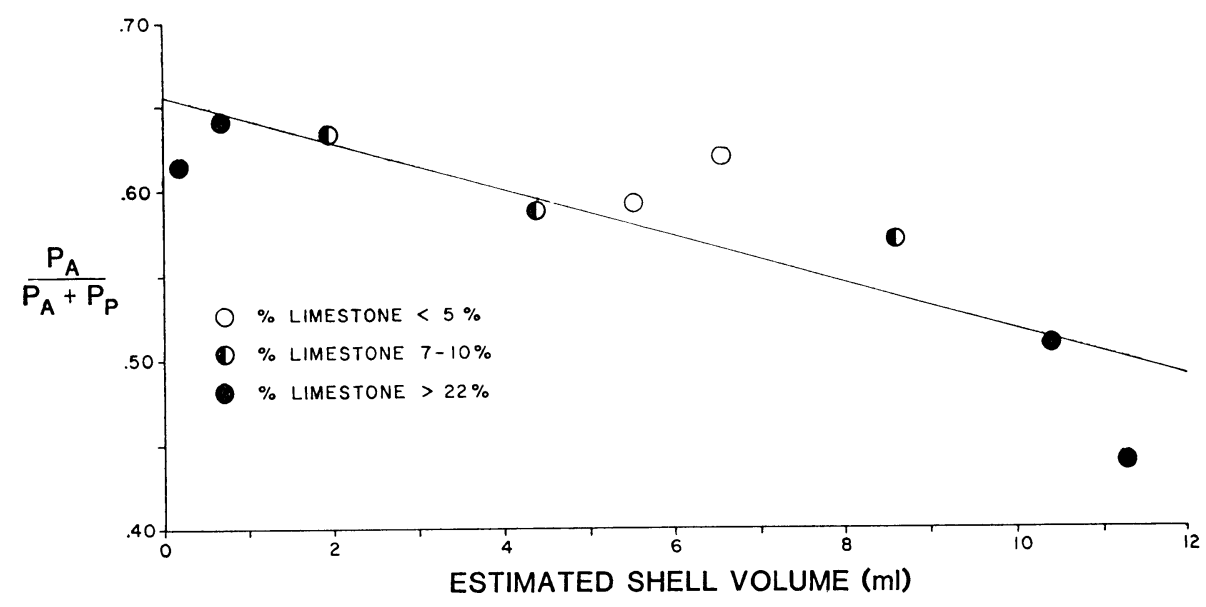

Fig 4. The proportion of non-limestone-derived shell carbonate carbon that is derived from the atmosphere vs estimated shell volume. The estimated percent of shell carbonate carbon derived from limestone is also indicated. The regression line is

$\frac{\mathbf{P}_{\mathrm{A}}}{\mathbf{P}_{\mathrm{A}}+\mathbf{P}_{\mathrm{P}}}=-0.0137$ (volume) $+0.654 ; \mathrm{r}=-0.851(\mathrm{p}<0.005)$ and $\mathrm{R}^{2}=0.724$. 
differ in the frequency of activity and, consequently, in rates of loss (by evaporation or through mucus during locomotion) and uptake of water from the ground. Exchange of $\mathrm{CO}_{2}$ with the atmosphere when snails are resting retracted into their shells is probably relatively unimportant. The rate of exchange would be reduced due to smaller exposed surface area and immobility of the air around the snail. The fact that there are no consistent ${ }^{13} \mathrm{C}$ differences between prosobranchs (which close off the mouth of the shell with an operculum when resting) and pulmonates (which do not have opercula) argues against the importance of $\mathrm{CO}_{2}$ exchange during inactivity. If exchange takes place primarily during activity, then differences in frequency of activity might produce differences in ${ }^{13} \mathrm{C}$ content. Variation in the relative importance of the urease mechanism in shell deposition may be an important determinant of shell carbonate carbon isotope levels. This is discussed in more detail below.

Magaritz and Heller (in press) propose that the ${ }^{13} \mathrm{C}$ content of shells of the land snail Theba pisana in Israeli deserts is largely determined through exchange with air. The ${ }^{13} \mathrm{C}$ content of the air would represent a combination of atmospheric $\mathrm{CO}_{2}$ and plant-derived $\mathrm{CO}_{2}$ resulting from respiration of dead plant material by decomposers. Part of the evidence for their conclusions comes from the observed enrichment of shell carbonate ${ }^{13} \mathrm{C}$ in juvenile snails relative to adults. The adults are believed to climb less than the juveniles and, thus, would be exposed more to air at the ground which might be expected to be relatively depleted in ${ }^{13} \mathrm{C}$ due to input from decomposition. Our data do not support this hypothesis of control of shell ${ }^{13} \mathrm{C}$ in Jamaican land snails. Eutrochatella pulchella, which lives exposed on top of (and sometimes under) limestone boulders, has almost exactly the same $\delta^{13} \mathrm{C}$ as Alcadia brownei, which lives among leaf litter and forages on top of leaf litter (Goodfriend, unpub observations). Poteria, which live and forage among leaf litter, rarely coming to the surface, show intermediate ${ }^{13} \mathrm{C}$ levels. Thus, habitat would not seem to be an important determinant of shell carbonate ${ }^{13} \mathrm{C}$ levels in these snails.

Because of the variety of factors affecting shell carbonate $\delta^{13} \mathrm{C}$, it seems unlikely that any generally applicable ecological (or paleoecological) interpretation of $\delta^{13} \mathrm{C}$ can be made. However, in well-studied situations, the effects of some of these factors could be assessed quantitatively. These effects could then be subtracted out from shell $\delta^{13} \mathrm{C}$, perhaps leaving a relatively pure ecological signal which could be used as a paleoenvironmental tool.

THE USE OF ${ }^{13} \mathrm{C}$ FOR CORRECTION FOR ISOTOPIC FRACTIONATION IN LAND SNAIL SHELL GARBONATE

In land snail shells that contain carbon derived from limestone, the relationship of ${ }^{14} \mathrm{C}$ and ${ }^{13} \mathrm{C}$ in the shell is not merely a function of fractionation processes but is due in part to mixing of carbon sources of different isotopic composition. Therefore, the standard fractionation correction factor (equation 3) cannot be applied. In shells without lime- 
stone-derived carbon, plants and atmospheric $\mathrm{CO}_{2}$ are the only carbon sources. Plant carbon is derived from atmospheric $\mathrm{CO}_{2}$ but its isotopic composition differs due to fractionation. The dissolution of $\mathrm{CO}_{2}$ in aqueous media also involves fractionation. In a snail shell without limestone carbon, fractionation is responsible ultimately for all deviations of $\delta^{13} \mathrm{C}$ from that of air. Therefore, in such shells, the standard correction for fractionation may be correctly applied.

For shells containing limestone-derived carbon, the carbon may be partitioned into two components: a limestone-derived portion (with $\delta^{13} \mathrm{C}$ $=0)$ and a non-limestone portion. The standard correction for isotopic fractionation may be applied only to this latter component. The ${ }^{14} \mathrm{C}$ activity of non-limestone carbon corrected for fractionation $\left(\mathrm{A}_{\mathrm{CNI}}\right)$ would be

$$
\mathrm{A}_{\mathrm{CNL}}=\mathrm{A}_{\mathrm{NL}}\left(\frac{\mathrm{R}_{\mathrm{NL}}}{\mathrm{R}_{\mathrm{MW}}}\right)^{2},
$$

where $\mathrm{A}_{\mathrm{NL}}$ is the uncorrected ${ }^{14} \mathrm{C}$ activity of the non-limestone derived portion of shell carbonate, expressed as percent of modern wood (MW). The observed (uncorrected) ${ }^{14} \mathrm{C}$ activity of the shell carbonate $\left(\mathrm{A}_{\mathrm{S}}\right)$ is the sum of the contributions of the two portions:

$$
\mathrm{A}_{\mathrm{S}}=\mathrm{P}_{\mathrm{NI}}\left(\mathrm{A}_{\mathrm{NL}}\right)+\mathrm{P}_{\mathrm{L}}(0) \text {. }
$$

Simplifying and rearranging, we have

$$
\mathrm{A}_{\mathrm{NI}}=\mathrm{A}_{\mathrm{S}} / \mathrm{P}_{\mathrm{NL}} \text {. }
$$

Substituting for $A_{N L}$ in equation 14 , we get

$$
\mathrm{A}_{\mathrm{CNL}}=\frac{\mathrm{A}_{\mathrm{S}}}{\mathrm{P}_{\mathrm{NL}}}\left(\frac{\mathrm{R}_{\mathrm{NL}}}{\mathrm{R}_{\mathrm{MW}}}\right)^{2} \text {. }
$$

Now, the ${ }^{14} \mathrm{C}$ activity of shell carbonate, corrected for fractionation $\left(\mathrm{A}_{\mathrm{C}}\right)$ would be

$$
\mathrm{A}_{\mathrm{C}}=\mathrm{P}_{\mathrm{NI}}\left(\mathrm{A}_{\mathrm{CNL}}\right)+\mathrm{P}_{\mathrm{L}}(0) .
$$

Substituting for $\mathrm{A}_{\mathrm{CNL}}$ from equation 17 and simplifying, we get

$$
A_{C}=A_{S}\left(\frac{R_{N L}}{R_{M W}}\right)^{2}
$$

Thus, the correction factor is simply the term for the correction for fractionation between the non-limestone portion of the shell relative to modern wood.

To express this in terms of the observed ${ }^{13} \mathrm{C}$ content of the shell $\left(\delta^{13} \mathrm{C}_{\mathrm{S}}\right)$, we note that

$$
\mathrm{R}_{\mathrm{NL}}=\left(1+\frac{\delta^{13} \mathrm{C}_{\mathrm{NL}}}{1000}\right) \mathrm{R}_{\mathrm{PDB}}
$$

and that (since $\delta^{13} \mathrm{C}_{\mathrm{S}}=\mathrm{P}_{\mathrm{NL}}\left(\delta^{13} \mathrm{C}_{\mathrm{NL}}\right)+\mathrm{P}_{\mathrm{L}}\left(\delta^{13} \mathrm{C}_{\mathrm{L}}\right)$ and $\delta^{13} \mathrm{C}_{\mathrm{L}}$ is taken to be 0 ) 


$$
\delta^{13} \mathrm{C}_{\mathrm{NL}}=\delta^{13} \mathrm{C}_{\mathrm{S}} / \mathrm{P}_{\mathrm{NL}}
$$

Substituting for $\delta^{13} \mathrm{C}_{\mathrm{NL}}$ in equation 20 from equation 21, substituting this expression for $R_{N L}$ in equation 19 , and taking $\delta^{13} C_{M W}$ as $0.975 R_{P D B}$, we get

$$
\mathrm{A}_{\mathrm{C}}=\mathrm{A}_{\mathrm{S}}\left(\frac{1+\frac{\delta^{13} \mathrm{C}_{\mathrm{S}}}{1000 \cdot \mathrm{P}_{\mathrm{NL}}} \cdot \mathrm{R}_{\mathrm{PDB}}}{0.975 \mathrm{R}_{\mathrm{PDB}}}\right)^{2}
$$

or

$$
\mathrm{A}_{\mathrm{C}}=1.052 \mathrm{~A}_{\mathrm{S}}\left(1+\frac{\delta^{13} \mathrm{C}_{\mathrm{S}}}{1000 \cdot \mathrm{P}_{\mathrm{NL}}}\right)^{2} .
$$

When $\mathrm{P}_{\mathrm{NL}}=1$ ( $i e$, when there is no limestone-derived carbon in the shell), equation 23 reduces to the standard correction.

Normally, $\mathrm{P}_{\mathrm{NL}}$ would not be known for radiocarbon-dated material from a limestone area. Therefore, it is of interest to know how much difference variation in $P_{N L}$ would make to estimates of corrected shell ${ }^{14} \mathrm{C}$ activity. We will examine the correction for fractionation for two extreme values of $\mathrm{P}_{\mathrm{NL}}: \mathrm{P}_{\mathrm{NL}}=1$ and $\mathrm{P}_{\mathrm{NL}}=0.65$ (the approximate observed minimum) and for the observed extreme values of $\delta^{13} \mathrm{C}_{\mathrm{S}}=-10.86 \%$ and $-6.41 \%$. For shells with no limestone-derived carbon $\left(\mathrm{P}_{\mathrm{NL}}=1\right)$, the fractionation-corrected ${ }^{14} \mathrm{C}$ activity $\left(\mathrm{A}_{\mathrm{C}}\right)$ would be $1.039 \mathrm{~A}_{\mathrm{S}}$ for $\delta^{13} \mathrm{C}_{\mathrm{S}}=$ $-6.41 \%$, and $1.029 \mathrm{~A}_{\mathrm{S}}$ for $\delta^{13} \mathrm{C}_{\mathrm{S}}=-10.86 \%$. For $\mathrm{P}_{\mathrm{NL}}=0.65, \mathrm{~A}_{\mathrm{C}}$ would be $1.031 \mathrm{~A}_{\mathrm{S}}$ for $\delta^{13} \mathrm{C}_{\mathrm{S}}=-6.41 \%$ and $1.017 \mathrm{~A}_{\mathrm{S}}$ for $\delta^{13} \mathrm{C}_{\mathrm{S}}=-10.86 \%$. Thus, for shells with maximal limestone carbon content, the correction in ${ }^{14} \mathrm{C}$ activity due to fractionation is ca $1 \%(0.8-1.2 \%)$ less than the correction factor for shells without limestone-derived carbon. This error is quite small in comparison to the ${ }^{14} \mathrm{C}$ anomaly due to limestone-derived carbon.

\section{HEMOLYMPH BICARBONATE ${ }^{13} \mathrm{C}$ AND ITS IMPLICATIONS FOR CARBON PATHWAYS \\ TO SHELL CARBONATE AND BICARBONATE-CARBONATE FRACTIONATION}

The small fractionation between aragonite and bicarbonate has been neglected in the analysis up to now. In an inorganic system with a large bicarbonate reservoir, precipitated aragonite was found to be enriched in ${ }^{13} \mathrm{C}$ by a factor of $\alpha=1.0027$ relative to bicarbonate. This amounts to a

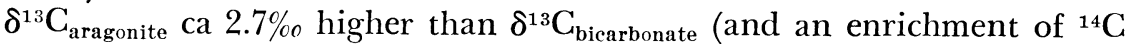
by $0.54 \%$ ). In order to test whether this fractionation also occurs in the land snail bicarbonate-aragonite system, the ${ }^{13} \mathrm{C}$ content of snail hemolymph bicarbonate and shell carbonate were measured.

We used four adult specimens of Pleurodonte lucerna which had been collected at Cedar Valley, southwestern St Ann Parish, Jamaica, in December, several weeks before the analyses, and which were maintained in the lab on Jamaican leaf litter. Hemolymph extraction was performed under a pure nitrogen atmosphere. The shells of the living snails were crushed and removed. The head-foot was cut longitudinally and the bodies were placed in $1 \mathrm{~mm}$ nylon mesh and gently squeezed to extract the body fluids (hemolymph). This extract (ca $2 \mathrm{ml}$ volume) was poured into 
a vial and sealed with a rubber stopper. It was then removed from the nitrogen atmosphere and frozen. Several days later is was quickly thawed and analyzed immediately. $1 \mathrm{~N} \mathrm{HCl}$ was used to convert the bicarbonate pool to $\mathrm{CO}_{2}$, which was collected and analyzed for ${ }^{13} \mathrm{C}$. These results concerning hemolymph ${ }^{13} \mathrm{C}$ must be taken as preliminary. Ideally, measurements should be made on hemolymph of snails immediately after their removal from the field. And subadult specimens (in which the shell is still growing) would be preferred over adults.

The $\delta^{13} \mathrm{C}$ of the hemolymph bicarbonate was $-8.72 \%$ and the shell carbonate for three shells had a mean $\delta^{13} \mathrm{C}$ of $-10.86 \%$. Thus, in contrast to the situation predicted by lab studies of fractionation, shell carbonate is depleted in ${ }^{13} \mathrm{C}$ relative to hemolymph bicarbonate. Since whole shells were analyzed, the shell $\delta^{13} \mathrm{C}$ represents an average $\delta^{13} \mathrm{C}$ over ca 6 months of the year (growth occurs from April to September in this population). The hemolymph $\delta^{13} \mathrm{C}$, however, represents a measurement at a particular time; this value may vary seasonally (Magaritz, Heller, and Volokita, 1981). Therefore, the estimated carbonate-hemolymph bicarbonate fractionation must be considered approximate.

There are good reasons not to expect the predicted equilibrium fractionation. Since the bicarbonate reservoir of the snail is relatively small, a positive fractionation of the initially deposited shell carbonate would produce a negative fractionation of the bicarbonate, which would counteract further fractionation effects in the shell. Furthermore, the deposition of shell carbonate may occur too rapidly for equilibrium to be reached. As an approximate estimate of the rate of turnover of bicarbonate in the process of shell deposition, let us consider Cedar Valley Pleurodonte lucerna. Adult snails have an average mass of ca $22 \mathrm{~g}$, of which ca $8 \mathrm{~g}$ is shell and $14 \mathrm{~g}$ body (wet mass). Ca $5 \mathrm{~g}$ of the shell is deposited during the period of activity (about half the year) during the final year of maturation. If the shell is $95 \%$ calcium carbonate (Degens, Spencer, and Parker, 1967), this would represent 0.0475 moles of calcium carbonate. The body is ca $85 \%$ water, or ca $12 \mathrm{~g}$ per individual. Taking an average hemolymph bicarbonate concentration of $20 \mathrm{mM}$ (Burton, 1969), a snail would contain ca $1.7 \times 10^{-4}$ moles of bicarbonate. Over the course of half a year, this would have to be turned over ca 280 times to produce the observed rate of shell growth. Thus, neither the reaction rate nor the reservoir size is equivalent to the conditions under which lab experiments of fractionation were run.

Dissolution of atmospheric $\mathrm{CO}_{2}$ at the mantle edge would seem to be unimportant, since this would tend to produce a higher shell carbonate $\delta^{13} \mathrm{C}$ relative to hemolymph bicarbonate. The urease mechanism of shell deposition (discussed above) probably accounts for the observed aragonitebicarbonate ${ }^{13} \mathrm{C}$ differences. Release of primarily plant-derived carbon from urea breakdown during shell deposition would decrease shell $\delta^{13} \mathrm{C}$ relative to hemolymph. If we assume this is the only process accounting for aragonite-bicarbonate ${ }^{13} \mathrm{C}$ differences and that urea is entirely derived from plant carbon $\left(\delta^{13} \mathrm{C}_{\mathrm{U}}=-27\right)$, then we can calculate the proportion of 
shell carbon that is derived from urea. Let $\mathrm{P}_{\mathrm{U}}$ represent the proportion of shell carbonate carbon derived from urea. Then

$$
\delta^{13} \mathrm{C}_{\mathrm{S}}=\mathrm{P}_{\mathrm{U}}\left(\delta^{13} \mathrm{C}_{\mathrm{U}}\right)+\left(1-\mathrm{P}_{\mathrm{U}}\right) \delta^{13} \mathrm{C}_{\mathrm{H}},
$$

where $\delta^{13} \mathrm{C}_{\mathrm{H}}$ is the $\delta^{13} \mathrm{C}$ of hemolymph bicarbonate. Substituting the observed values for Cedar Valley Pleurodonte lucerna we get

$$
\begin{gathered}
-10.86=\mathrm{P}_{\mathrm{U}}(-27)+\left(1-\mathrm{P}_{\mathrm{U}}\right)(-8.72) \\
\text { or } \mathrm{P}_{\mathrm{U}}=0.117 .
\end{gathered}
$$

Since ${ }^{14} \mathrm{C}$ analyses were not performed on these specimens, $P_{P}$ is not known but is probably near 0.39 (the mean of $P$ lucerna and $P$ sublucerna in table 1). Urea-derived plant carbon would thus represent some $30 \%$ of this. Note that this is a minimum estimate of the urea contribution to shell carbon. If urea also contains some carbon derived from the bicarbonate pool (and it probably does - see Tramell and Campbell, 1972), or if there is some fractionation or diffusion of atmospheric $\mathrm{CO}_{2}$ into the mantle associated with shell deposition, then the contribution of urea carbon would be higher than estimated.

Differences among taxa in the presence, absence, or quantitative importance of the urea breakdown (Loest, 1979) would be expected to produce differences in the contribution of plant carbon to shell carbonate and thus produce variation in ${ }^{13} \mathrm{C}$ content. Unfortunately, analysis of carbon isotopes has not been used to examine these aspects of the physiology of shell deposition. Such studies would probably be of considerable value in understanding the processes occurring during shell deposition.

\section{ORGANIC CARBON IN LAND SNAIL SHFLLS}

The current development of accelerator methods to concentrate ${ }^{14} \mathrm{C}$ may make it possible in the near future to date much smaller quantities of carbon than is presently possible. As pointed out by Burleigh and Kerney (1982), this should make it possible to analyze shell organics for ${ }^{14} \mathrm{C}$. Therefore, a knowledge of the source of shell organic carbon is of considerable interest. It has been assumed (De Niro and Epstein, 1978; Burleigh and Kerney, 1982) that land snail shell organics (which are primarily proteins) are derived entirely from ingested plant material and therefore, assuming no fractionation, should have a $\delta^{13} \mathrm{C}$ identical to plant material.

We have performed ${ }^{13} \mathrm{C}$ analyses on shell organics of two species (table 3). For both species, the $\delta^{13} \mathrm{C}$ is within the range observed for tropical plants (Degens, 1969) but both are a little lower than average. Due to the

TAble 3

${ }^{13} \mathrm{C}$ analyses of shell organic carbon

\begin{tabular}{lcll}
\hline Species & $\mathrm{N}$ & Locality & $\delta^{13} \mathrm{C}(\% \circ)$ \\
\hline Pleurodonte lucerna & 2 & Colliston & -25.89 \\
Poteria varians & 4 & Albion & -26.22 \\
\hline
\end{tabular}


variation in plant ${ }^{13} \mathrm{C}$, it is not possible to tell whether these values differ from ingested plant material.

De Niro and Epstein (1978) carried out a series of experiments in which the ${ }^{13} \mathrm{C}$ content of plant material fed to land snails (Helix aspersa) was carefully controlled. They found the $\delta^{13} \mathrm{C}$ of the newly deposited shell organics to be ca $1 \%$ higher than the diet, which is consistent with our own findings. This enrichment could not be accounted for by differential loss of lighter carbon by respiration or defecation, or by differential incorporation of lighter carbon into biomass. The possibility of differential incorporation of lighter carbon into excreted uric acid or into mucus lost during locomotion was suggested by the authors.

A more likely explanation for the enrichment of shell organic ${ }^{13} \mathrm{C}$ relative to ingested plants is that it contains some carbon derived from inorganic sources. Land snails are known to incorporate hemolymph bicarbonate into a number of amino acids: arginine (Horne, 1977; Tramell and Campbell, 1972), alanine, aspartic acid, glutamic acid (Awapara and Campbell, 1964), glycine, proline, and serine (Tramell and Campbell, 1972; Campbell and Speeg, 1968). Taken together, these amino acids make up a considerable portion of land snail shell protein (Degens, Spencer, and Parker, 1967).

In general, we can partition the shell organic carbon sources into plant material and hemolymph bicarbonate. Thus

$$
\delta^{13} \mathrm{C}_{\mathrm{SO}}=\left(1-\mathrm{P}_{\mathrm{H}}\right)\left(\delta^{13} \mathrm{C}_{\mathrm{P}}\right)+\mathrm{P}_{\mathrm{H}}\left(\delta^{13} \mathrm{C}_{\mathrm{H}}\right),
$$

where $\delta^{13} \mathrm{C}_{\mathrm{SO}}$ represents the $\delta^{13} \mathrm{C}$ of shell organic carbon and $\mathrm{P}_{\mathrm{H}}$ is the proportion of shell organic carbon derived from hemolymph bicarbonate. If we take $\delta^{13} \mathrm{C}_{\mathrm{P}}$ as $-27 \%$ and $\delta^{13} \mathrm{C}_{\mathrm{II}}$ as $-8.7 \%$ (measurement obtained for Pleurodonte lucerna, above), and if we assume that shell organic carbon has a $\delta^{13} \mathrm{C} 1 \%$ higher than plants $\left(\delta^{13} \mathrm{C}_{\mathrm{SO}}=-26 \%\right)$, then

$$
\begin{gathered}
-26=\left(1-\mathrm{P}_{\mathrm{H}}\right)(-27)+\mathrm{P}_{\mathrm{H}}(-8.7) \\
\quad \text { or } \mathrm{P}_{\mathrm{II}}=0.0546 .
\end{gathered}
$$

So under these assumptions, ca $5 \%$ of the shell organic carbon is derived from hemolymph bicarbonate. In limestone areas, some of this bicarbonate will have been derived from limestone (Goodfriend and Stipp, in press) and thus the bicarbonate and shell organic fraction derived from it will be deficient in ${ }^{14} \mathrm{C}$. If we take $1 / 3$ as the upper limit of $\mathrm{P}_{\mathrm{L}}$, then up to $1 / 3$ $(0.0546)=1.82 \%$ of shell organic carbon may be effectively lacking in ${ }^{14} \mathrm{C}$. Using Tamer's (1970) formula, this amounts to an age anomaly of ca 150 years. For most dating purposes, this is not a serious error. But for certain archaeological purposes, this would not be acceptable.

Note that the estimate of $\mathrm{P}_{\mathrm{H}}$ is a minimum estimate of the proportion of inorganic carbon fixed in shell organics. Many of the reactions in which carbon is incorporated into amino acids are associated with the TCA cycle or other reactions that take place in mitochondria (Gilles, 1970; Horne, 1977). Here $\mathrm{CO}_{2}$ released from respiration of plant material would 
probably be a more important source for inorganic carbon. This carbon is included within the $\left(1-\mathrm{P}_{\mathrm{H}}\right)$ term in equation 25 . Thus, the total proportion of inorganic carbon fixed in shell organics may considerably exceed the estimate for hemolymph-derived inorganic carbon.

\section{CONCLUSIONS AND SUMMARY}

1) From $0-33 \%$ of land snail shell carbonate carbon comes from limestone, while $25-40 \%$ is derived from plants, and $30-62 \%$ from atmospheric $\mathrm{CO}_{2}$.

2) The proportion of limestone-derived carbonate carbon shows only a weak correlation with shell $\delta^{13} \mathrm{C}$. Therefore, $\delta^{13} \mathrm{C}$ is of limited use for calculating the proportion of limestone-derived carbon in radiocarbon dated material. The effect of limestone on shell ${ }^{13} \mathrm{C}$ content is obscured by other factors and by an apparent weak negative interaction with the atmospheric $\mathrm{CO}_{2}$ contribution to the shell.

3) Different taxa tend to differ with respect to carbonate $\delta^{13} \mathrm{C}$. This is probably in part due to size differences and consequent differences in the rate of exchange with atmospheric $\mathrm{CO}_{2}$. Differences in physiology and activity patterns may also contribute to observed ${ }^{13} \mathrm{C}$ variation. The contribution of carbon from urea breakdown is probably an important source of variation among species.

4) The variety of factors affecting land snail shell carbonate $\delta^{13} \mathrm{C}$ makes a generally applicable paleoecological interpretation of its level unlikely. However, $\delta^{13} \mathrm{C}$ could still prove useful in specific well-studied situations.

5) A formula for correcting the ${ }^{14} \mathrm{C}$ activity of land snail shell carbonate for fractionation is presented. In shells with a high content of limestone-derived carbon, the effect of fractionation is ca $1 \%$ less than would be calculated by the conventional formula.

6) There is no evidence for fractionation during precipitation of land snail shell aragonite from bicarbonate.

7) $\delta^{13} \mathrm{C}$ of land snail hemolymph bicarbonate is ca $2 \%$ higher than shell carbonate in adults collected in December. The difference is probably due to input of plant-derived carbon from urea breakdown in the mantle during shell deposition.

8) Shell organic carbon is largely derived from plant material but apparently also contains carbon derived from hemolymph bicarbonate. This makes it subject to a small age anomaly (estimated at up to ca 150 years) due to incorporation of carbon ultimately derived from limestone.

\section{ACKNOWLEDGMENTS}

We would like to thank E S Deevey, Jr, Mordecai Magaritz, K M Wilbur, J J Stipp, A J Kohn, and A C Riggs for helpful discussion and/or comments on the manuscript. Richard Burleigh, Joseph Heller, and Mordecai Magaritz kindly made their unpublished manuscripts available to us. Figures were prepared by W L Adams. 
APPENDIX

Land snails analyzed for carbon isotopes. Where indicated, voucher specimens are on deposit at the Academy of Natural Sciences of Philadelphia (ANSP) or the Florida State Museum (UF).

Alcadia brownei (Gray) Sta SN-153, E side of hill on W side of trail continuing from end of $\mathrm{Rd}$ No. $197,1.3 \mathrm{~km} \mathrm{~N}$ of junction with Alexandria-Alderton Rd, Higgin Land, St Ann, Jamaica; 580m elevation; 23-XI-1976; G Goodfriend (all specimens destroyed for analysis).

Eutrochatella pulchella (Gray) Jamaica (ANSP 183398).

Pleurodonte carmelita (Fér) Chester Vale, St Andrew, Jamaica; 955m; 1932; E A Andrews (ANSP 322415).

Pleurodonte lucerna (Müller) Sta BH, slope S of C Lindo's sugar factory, Broom Hall, SW of Cave Valley (St Ann), Clarendon, Jamaica; 640m; 22-XII-1980; G Goodfriend (UF 40248, 23-III-1977).

Pleurodonte lucerna Sta Ma-25, SW side of Heron Hill, at junction of Kendal Rd and Rte B6, Shooters Hill, N of Mandeville, Manchester, Jamaica; 425m; 7-IX-1980; G Goodfriend (UF 40247).

Pleurodonte lucerna Sta Ma-30, W side of hill along ridge, SE of Percy Junor Hospital, $1 \mathrm{~km} \mathrm{~W}$ of junction at Spaldings (Clarendon), Manchester, Jamaica; 825m; 17-IX1980; G Goodfriend (UF 40246).

Pleurodonte lucerna Sta SN-37, on low hill above entrance to Green Grotto Caves, S side of Rte $\mathrm{Al}$, ca $4.3 \mathrm{~km}$ E of junction at Discovery Bay, St Ann, Jamaica; 25m; 23-XII1981; G Goodfriend (UF 40242, 5-I-1979).

Pleurodonte lucerna Sta SN-102, base of cliff on $\mathrm{S}$ side of end of $\mathrm{rd}$ through Colliston (from Lower Buxton), E of Brown's Town, St Ann, Jamaica; 505m; 20-IX-1976; G Goodfriend (UF 40244).

Pleurodonte lucerna Sta SN-137, N side of hill $150 \mathrm{~m} \mathrm{~S}$ of Rd No. 146, $1.8 \mathrm{~km}$ WSW of junction with Rte B3 at Clarksonville, Cedar Valley, St Ann, Jamaica; 610m; 23XII-1981; G Goodfriend (UF 40243, XII-1978).

Pleurodonte lucerna Sta We-20, base of SW side of hill on N side of Lambs R - Rat Trap Rd, $0.8 \mathrm{~km} \mathrm{E}$ of junction at Rat Trap, Cow Park, Westmoreland, Jamaica; 350-365m; 27-XII-1981; G Goodfriend (UF 40245).

Pleurodonte sublucerna (Pilsbry) limestone hill just above reservoir spring and catchment basin, Port Antonio, Portland, Jamaica; 3-VII-1932; E A Andrews ("P acuta lamarckii", ANSP 162377).

Poteria jamaicensis (Gray) Somerset, Manchester, Jamaica; 1910; A Brown ("Ptychocochlis jamaicensis", ANSP 100850).

Poteria varians (C B Adams) Sta SN-141, escarpment $600 \mathrm{~m} \mathrm{~N}$ of ruins of Alexandria House, Alexandria Pen, E of Alexandria, St Ann, Jamaica; 625-655m; 20-XI-1976; $G$ Goodfriend (all specimens destroyed for analysis).

Poteria varians Sta SN-164, hill on SW side of Alexandria-Alderton Rd, ca $200 \mathrm{~m}$ SSW of junction with rd to Albion House, Albion, St Ann, Jamaica; 655-680m; 22-XII1976; G Goodfriend (all specimens destroyed for analysis).

Urocoptis ambigua (C B Adams) Somerset, Manchester, Jamaica; 1910; A P Brown (ANSP 101150).

Urocoptis ambigua Sta Ma-27, W side of hill at S end of red mud lake, ca $175 \mathrm{~m}$ NNW of junction of old Kendal Rd and new bypass rd, Martins Hill, $\mathrm{N}$ of Mandeville, Manchester, Jamaica; 535m; 16-IX-1980; G Goodfriend (UF 40241).

Urocoptis megacheila (Chitty) Sta We-8, SW side of hill, $450 \mathrm{~m}$ E of rd from Cave Valley to Delve Bridge, $0.7 \mathrm{~km} \mathrm{~S}$ of junction with rd to Retrieve Mt, Midgham dist, Westmoreland, Jamaica; 200m; 1-I-1979; G Goodfriend (ANSP 353836).

\section{REFERENCES}

Awapara, J and Campbell, J W, 1964, Utilization of $\mathrm{C}^{14} \mathrm{O}_{2}$ for the formation of some amino acids in three invertebrates: Comp Biochem Physiol, v 11, p 231-235.

Barrette, L, Lasalle, P, Martel, Y, and Samson, C, 1980, Variation of ${ }^{14} \mathrm{C}$ in oats grown from 1957 to 1978 in Quebec, in Stuiver, Minze and Kra, Renee, eds, Internatl radiocarbon conf, 10th, Proc: Radiocarbon, v 22, no. 2, p 410-414.

Bøggild, O B, 1930, The shell structure of the mollusks: Kgl Danske Vidensk Selsk Skr, Naturvidensk Mat, afd 9, no. 2, p 233-326.

Burleigh, R and Kerney, M P, 1982, Some chronological implications of a fossil molluscan assemblage from a Neolithic site at Brook, Kent, England: Jour Archeol Sci, v 9, p 29-38. 
Burton, R F, 1969, Buffers in the blood of the snail, Helix pomatia L: Comp Biochem Physiol, v 29, p 919-930.

Cain, W F, 1979, ${ }^{14} \mathrm{C}$ in modern American trees, in Berger, $\mathrm{R}$ and Suess, $\mathrm{H} \mathrm{E}$, eds, Radiocarbon dating, Internatl radiocarbon conf, 9th, Proc: Berkeley, Univ California Press, p 495-510.

Campbell, J W and Boyan, B D, 1976, On the acid-base balance of gastropod molluscs, in Watabe, $\mathrm{N}$ and Wilber, $\mathrm{K} \mathrm{M}$, eds, The mechanisms of mineralization in the invertebrates and plants: Columbia, Univ South Carolina Press, p 109-133.

Campbell, J W and Speeg, K V, Jr, 1968, Arginine biosynthesis and metabolism in terrestrial snails: Comp Biochem Physiol, v 25, p 3-32. v 224, p 725-726.

Chan, W and Saleuddin, A S M, 1974, Evidence that Otala lactea (Muller) utilizes calcium from the shell: Malacol Soc London Proc, v 41, p 195-200.

Craig, Harmon, 1954, Carbon 13 in plants and the relationships between carbon 13 and carbon 14 variations in nature: Jour Geol, v 62, p 115-149.

De Jorge, F B and Haeser, P E, 1968, Further biochemical studies on the snail Strophocheilus oblongus musculus Becquaert, 1948: Comp Biochem Physiol, v 26, p 627-637.

De Niro, M J and Epstein, S, 1978, Influence of diet on the distribution of carbon isotopes in animals: Geochim et Cosmochim Acta, v 42, p 495-506.

Degens, E T, 1969, Biogeochemistry of stable carbon isotopes, in Eglinton, G and Murphys, M T J, eds, Organic geochemistry: New York, Springer-Verlag, p 304-329.

Degens, E T, Spencer, S W, and Parker, R H, 1967, Paleobiochemistry of molluscan shell proteins: Comp Biochem Physiol, v 20, p 553-579.

Emrich, K, Ehhalt, D H, and Vogel, J C, 1970, Carbon isotope fractionation during the precipitation of calcium carbonate: Earth Planetary Sci Letters, v 8, p 363-371.

Fournié, J and Chétail, M, 1982, Accumulation calcique au niveau cellulaire chez les mollusques: Malacologia, v 22, p 265-284.

Frick, W, 1965, Der Kalziumstoffwechsel bei Helix pomatia unter dem Einfluss wechselnder Kohlensäureatmosphären: Mitt Zool Mus Berlin, v 41, p 95-120.

Fritz, $\mathrm{P}$ and Poplawski, S, 1974, ${ }^{18} \mathrm{O}$ and ${ }^{13} \mathrm{C}$ in the shells of freshwater molluscs and their environments: Earth Planetary Sci Letters, v 24, p 91-98.

Gilles, R, 1970, Intermediary metabolism and energy production in some invertebrates: Arch Internatl Physiol Biochim, v 78, p 313-326.

Goodfriend, G A and Stipp, J J, 1983, Limestone and the problem of radiocarbon dating of land snail shell carbonate: Geology, v 11, no. 10, p 575-577.

Horne, F R, 1973, Urea metabolism in an estivating terrestrial snail Bulimulus dealbatus: Am Jour Physiol, v 224, p 781-787.

1977, Regulation of urea biosynthesis in the slug, Limax flavus Linne: Comp Biochem Physiol, v 56B, p 63-69.

Loest, R A, 1979, Ammonia-forming enzymes and calcium-carbonate deposition in terrestrial pulmonates: Physiol Zool, v 52, p 470-483.

Magaritz, $\mathrm{M}$ and Heller, J, in press, Effect of the micro-environment on the ${ }^{18} \mathrm{O} /{ }^{18} \mathrm{O}$ and ${ }^{13} \mathrm{C} /{ }^{12} \mathrm{C}$ isotope ratios in landsnail shells: Isotope Geoscience, in press.

Magaritz, M, Heller, J, and Volokita, M, 1981, Land-air boundary environment as recorded by the ${ }^{18} \mathrm{O} /{ }^{16} \mathrm{O}$ and ${ }^{13} \mathrm{C} /{ }^{12} \mathrm{C}$ isotope ratios in the shells of land snails: Earth Planetary Sci Letters, v 52, p 101-106.

Mook, W G, Bommerson, J C, and Staverman, W H, 1974, Carbon isotope fractionation between dissolved bicarbonate and gaseous carbon dioxide: Earth Planetary Sci Letters, v 22, p 169-176.

Mook, W G and Vogel, V C, 1968, Isotopic equilibrium between shells and their environment: Science, v 159, p 874-875.

Poulicek, M and Jaspar-Versali, M F, 1982, Essai d'interpretation d'un cycle saisonnier de la limacelle chez quelques pulmones Limacidae: Malacologia, v 22, p 241-244.

Pusswald, A W, 1948, Beitrage zum Wasserhaushalt der Pulmonaten: Zeitschr Vergl Physiol, v 31, p 227-248.

Rubin, M, Likins, R C, and Berry, E G, 1963, On the validity of radiocarbon dates from snail shells: Jour Geology, v 71, p 84-89.

Rubinson, $\mathrm{M}$ and Clayton, R N, 1969, Carbon-13 fractionation between aragonite and calcite: Geochim et Cosmochim Acta, v 33, p 997-1002.

Speeg, K V, Jr and Campbell, J W, 1968, Formation and volatilization of ammonia gas by terrestrial snails: Am Jour Physiol, v 214, p 1392-1402. 
Tamers, M A, 1970, Validity of radiocarbon dates on terrestrial snail sheils: Am Antiquity, v 35, p 94-100.

Tramell, P R and Campbell, J W, 1972, Arginine and urea metabolism in the South American land snail, Strophocheilus oblongus: Comp Biochem Physiol, v 42B, p 439-449.

Wigley, T M L and Muller, A B, 1981, Fractionation corrections in radiocarbon dating: Radiocarbon, v 23, p 173-190.

Wilbur, K M, 1972, Shell formation in mollusks, in Florkin, M and Scheer, B T, eds, Chemical zoology, vol 7, Mollusca: New York, Academic Press, p 103-145.

Yapp, C J, 1979, Oxygen and carbon isotope measurements of land snail shell carbonate: Geochim et Cosmochim Acta, v 23, p 629-635. 